\title{
Interns' depressive symptoms evolution and training aspects: a prospective cohort study
}

Daniela Betinassi Parro-Pires ${ }^{1}$ Luiz Antônio Nogueira-Martins²

Vanessa de Albuquerque Citero ${ }^{3}$

\begin{abstract}
1. Psych, MSc. Psychologist, Department Psychiatry, Escola Paulista de Medicina, Universidade Federal de São Paulo (EPM/UNIFESP), São Paulo (SP), Brasil. 2. MD, PhD. Former Professor, Department Psychiatry, Escola Paulista de Medicina, Universidade Federal de São Paulo (EPM/UNIFESP), São Paulo (SP), Brasil. 3. MD, PhD. Affiliated Professor, Department Psychiatry, Escola Paulista de Medicina, Universidade Federal de São Paulo (EPM/UNIFESP), São Paulo (SP), Brasil.
\end{abstract}

http://dx.doi.org/10.1590/1806-9282.64.09.806

\section{SUMMARY}

OBJECTIVE: To study depression symptoms' incidence of medical interns (first year of medical residency) and its correlation with occupational characteristics, satisfaction and stress about their training program.

METHODS: Prospective Cohort Study conducted at Escola Paulista de Medicina, Universidade Federal de São Paulo. First year residents, $N=166$, from a teaching hospital were invited to answer the Beck Depression Inventory (BDI) and an occupational questionnaire in a prospective longitudinal study. BDI score variation was related with socio-demographic aspects and occupational characteristics using linear regression models.

RESULTS: 111 subjects participated (67\%); the BDI-score increased in 8 months (mean $=2.75 \pm 3.29$ vs. $7.00 \pm 5.66 ; p<0.0001$ ). The depressive symptoms' incidence was 9.01\% (score $>15)$. BDI-score variation had mean $=4.25 \pm 4.93$, ranging from -8 to 28 . Residents not satisfied with professional training acquired $(\beta=3.44 ; p=0.004)$, with their personal life $(\beta=2.97 ; p=0.001)$, or who felt stressed in the relationship with senior residents $(\beta=2.91 ; p=0.015)$ presented 3 more points of BDI-score after 8 months comparing to those without these perceptions; and being unsatisfied with the nursing team increased BDI-score after 8 months in 2 more points ( $\beta=1.95$; $p=0.025)$.

CONCLUSION: Among the factors that interfere with depression in interns is the occupational characteristics, which might be enhanced by the training facility. Addressing these dissatisfaction and stressful issues should help the university provide better care of interns' mental health.

KEYWORDS: Depression. Internship and Residency. Stress, psychological. Mental health. Educational, medical.

\section{INTRODUCTION}

It is known that to become a physician many stressful challenges have to be faced. However, it must be acknowledged that at a certain level, this situation is no longer bearable and starts to harm the medical intern (first year of postgraduate medical residency) and resident. Studies on mental health of doctors, residents, interns and medical students have been substantially published over the years. ${ }^{1-10}$ Depressive symptoms in medical residents related to individual characteristics, educational and occupational environment, have been an aspect of particular importance. ${ }^{1,8-11}$ 
It has been described ${ }^{1}$ that the typical intern goes through distinct phases during the first postgraduate year. It begins with an initial stage of excitement as the year begins. This period is followed by one of self-doubt when the intern begins to recognize his/ her limitations. Depressive symptoms may follow and then it starts a quiet, often tedious period, and by mid-year, another period of more intense depression may ensue. After the $9^{\text {th }}$ month the intern begins to recognize the tangible accomplishments and enters the stage of success.

Another study described "the house officer stress syndrome". It was stated that residents present episodic cognitive impairment, chronic anger, pervasive cynicism, family discord, depression, suicidal ideation and suicide, and substance abuse. Some factors were associated as the aetiology of this syndrome: sleep deprivation, excessive work load, patient care responsibility, perpetually changing work conditions, and peer competition. ${ }^{12}$

In a three year prospective study, ${ }^{3}$ internal medicine residents indicated their level of agreement answering questions about their emotional state. Depression reached its highest level during the first year, mainly between the $6^{\text {th }}$ and $8^{\text {th }}$ month, and lessened significantly and rapidly after the $13^{\text {th }}$ month.

Depressive symptoms prevalence for medical residents has been studied in several researches. One of these found depressive symptoms in $28.7 \%$ of postgraduate year 1 (PGY-1), 21.5\% of PGY-2 and 10.3\% of PGY-3. ${ }^{2}$ Other study conducted during a 3-year period showed the evolution of depressive symptoms in internal medicine residents: they started low, peaked between the $7^{\text {th }}$ and $9^{\text {th }}$ month of the first year and improved by the end of internship; on the $2^{\text {nd }}$ and $3^{\text {rd }}$ years, residents improved to the point where they were not different from baseline. ${ }^{5}$ The prevalence of moderate depression increased from $4.3 \%$ at the beginning of residency to $29.8 \%$ after one year, however no one had scores indicating severe depression. ${ }^{6}$ In another study conducted during one year, a lower percentage of interns presented medium and high levels of symptoms of depression at the beginning of the year; this percentage peaked in the fourth month, and showed a second elevation at the end of the year. ${ }^{4}$

In a systematic review and meta-analysis, a pooled prevalence of depression or depressive symptoms among resident physicians was 28.8\% (from $20.9 \%$ to $43.2 \%$ ) and this study presented heterogeneity as included interns, residents, cross-sectional and longitudinal studies. In secondary analysis restricted to longitudinal studies, it was found a significant increase in depressive symptoms among interns after the start of residency, the median absolute increase in depressive symptoms among interns was $15.8 \%$ within a year of beginning training (range from $0.3 \%$ to $26.3 \%$ ). No statistically significant differences were observed between cross-sectional vs longitudinal studies, studies with interns only vs upper-level residents only, or studies of nonsurgical vs both nonsurgical and surgical residents. ${ }^{11}$

The association between depressive symptoms and medical residency has been presented as a popular topic, but its popularity is a double-edged sword. Much has been published in this domain, and it is unclear how new studies could advance the field beyond what is already known. Some factors related are a two-way causal relationship, i.e., a reverse causation, such as depressive symptoms and dissatisfaction with the training.

In a prospective longitudinal cohort study we aimed at identifying the incidence of depressive symptoms in interns; identifying depressive symptoms' association with some occupational characteristics (considering dissatisfaction, stressful situations and difficulties with the training program); and assessing whether the depressive symptoms are related to the quality of the training received (considering their opinion about the education received); and to peer and teamwork relationship and to stressful patients.

\section{METHODS}

In 2006, 166 new interns entered the medical residency programs in a teaching hospital. All of them were invited to participate in the study, and were told that their participation would be voluntary and only aggregated group data would be reported. This study was approved by the university's institutional review board. Written informed consent was obtained from each study participant.

One hundred forty-six interns answered the instruments at the baseline survey (T1). There was no statistically significant difference $(\mathrm{P}<0.05)$ between them and the 20 interns who did not answer the instruments according to gender, age and residency program. Data about gender, age, and residency program for these 20 interns was obtained from the administrative record of interns in the university. 
On the $8^{\text {th }}$ month, all those 146 interns were invited to answer the second survey (T2), which was completed by 112 interns. Thirty-four interns did not participate due to refusal, vacation or work in a medical facility outside the university hospital. The data of the 34 interns, who did not answer the second survey (at T2), did not differ significantly from those 112 who answered them considering gender, age, BDI score at $\mathrm{T} 1$ and residency program $(\mathrm{P}<0.05)$.

In order to calculate the incidence at the eighth month, the one intern who scored for depressive symptoms at $\mathrm{T} 1$ was excluded. Thus, the set of data analysed was composed of 111 interns, 67\% of 166 interns (answered both phases).

At the orientation session (T1) - a meeting in which general guideline for the training is provided to all new residents - during the first week of the medical residency program, each intern received personally the consent form, the socio-demographic questionnaire and the Brazilian version ${ }^{13,14}$ of the Beck Depression Inventory (BDI) ${ }^{15}$ and they were asked to return them in the session. The interns who did not return them or did not appear during orientation session were contacted by one of the researchers during the following days until 20 days after this session. During the first month, 18 new interns were admitted in substitution of dropouts and received the questionnaire and instrument to be answered in their first day at admission office. Eight months later (T2) all interns who answered T1 received personally the BDI and a questionnaire about occupational characteristics during the training.

For the purpose of the analysis, the residency programs were grouped in two major sections: clinical area, including dermatology, family medicine, infectious diseases, internal medicine, medical genetic, neurology, paediatrics, physical medicine and rehabilitation, and psychiatry; and surgical area, including anaesthesiology, neurosurgery, otorhinolaryngology, obstetrics and gynaecology, ophthalmology, orthopaedics, and general surgery.

The socio-demographic questionnaire comprises data about gender, age, marital status, place of birth, medical school, number of years living in that city, place where the intern was living during training, whether the resident was on mental health treatment, and personal/family psychiatric history. The $\mathrm{BDI}^{15}$ assesses the existence and severity of depression symptoms, considering a cut-off score higher than 15 as depressive symptoms according to the
Brazilian validation. ${ }^{14}$ The questionnaire on occupational characteristics during training is a self-report structured questionnaire developed for this study that explores the intern's difficulties during the first 8 months of training. The questionnaire covers training dissatisfaction, difficulty with patients, and stressful relationships.

BDI scores at $\mathrm{T} 1$ and $\mathrm{T} 2$ were analysed, and the incidence of depressive symptoms was calculated. Both scores were compared using the Wilcoxon Signed-Rank Test, and they were distributed by social-demographic characteristics using the Mann-Whitney Test.

Thus, the difference of BDI scores at T2 and T1 was calculated to each subject. This new variable, the "BDI scores variation" was the main outcome studied in a series of linear regressions. First, univariate linear regression models were developed to evaluate the relationship between the BDI score variation and each of the following items: training dissatisfaction, stressful relationships, difficulty in dealing with patients, work load, gender, specialty area and age.

Second, these linear regression models were adjusted using gender, specialty and age as controlling variables of the others, simultaneously, using the entry method. Third, variables with no statistically significant associations $(p>0.05)$ were excluded, one by one, in order of significance (backward method).

The regression linear models presented, as one of the assumption, a normal distribution of the outcome variable which were verified using Kolmogorov-Smirnov test $(\mathrm{p}=0.071)$. There were not any multicollinearity problems (according to VIF) and the residual analysis did not indicate existence of influence points. It was used $5 \%$ significance level to all statistical tests.

The statistical analysis was carried out using SPSS 20.0 software.

This study was approved by the university's institutional review board and written informed consent was obtained from each study participant.

\section{RESULTS}

The group of 111 interns, who did not score for depressive symptoms at $\mathrm{T} 1$, and answered both phases (67\% of 166 interns) was considered for the analysis.

The 111 interns were $50.5 \%$ female, with median age of 25 years old (ranged from 23 to 30 ) and all Brazilian. More than 60\% (61.3\%) of interns obtained 
their undergraduate degree as medical doctors in the same medical school where this study was developed. The socio-demographic characteristics are showed in Table 1.

Ten of the 111 interns scored for depression symptoms at $\mathrm{T} 2$ in the BDI inventory. Both BDI scores showed an asymmetric distribution, with median of 2 (mean of 2.75 , standard deviation of 3.29 , ranged from 0 to 14) at T1 and median of 5 (mean of 7.00, standard deviation of 5.66, ranged from 0 to 30 ) at $\mathrm{T} 2$. There was an increase in BDI score from $\mathrm{T} 1$ to $\mathrm{T} 2$ $(\mathrm{z}=-7.43 \mathrm{P}<0.0001)$, and the incidence of depressive symptoms after 8 months of training was $9.01 \%$ (cutoff score higher than 15).

Of all 10 interns who scored for depressive symptoms, only one was under mental health treatment. Additionally, another 11 interns who did not score for depressive symptoms reported to be under mental health treatment (medication and/or psychotherapy).

BDI scores showed differences across different sub-populations of the study related to socio-demographic characteristics (Table 2). At T1, it was found a statistically significant difference between interns who lived with relatives and those who did not (BDI mean score of $1.96 \pm 2.92$ versus $3.44 \pm 3.46 ; \mathrm{z}=-2.84$,

TABLE 1. SOCIO-DEMOGRAPHIC CHARACTERISTICS OF THE 111 MEDICAL RESIDENTS IN THE STUDY COLLECTED AT BASELINE SURVEY (T1)

\begin{tabular}{|c|c|c|c|}
\hline & & $\mathrm{N}$ & $\%$ \\
\hline \multirow[t]{2}{*}{ Residency Programs } & Surgical & 43 & 38.7 \\
\hline & Clinical & 68 & 61.3 \\
\hline \multirow[t]{2}{*}{ Medical School } & $\begin{array}{l}\text { The same that the subject } \\
\text { is intern }\end{array}$ & 68 & 61.3 \\
\hline & Other & 43 & 38.7 \\
\hline Marital status & Single & 106 & 95.5 \\
\hline \multirow{2}{*}{$\begin{array}{l}\text { Years living in São Paulo } \\
\text { (city where the univer- } \\
\text { sity is) }\end{array}$} & $<6$ years & 40 & 36.7 \\
\hline & $\geq 6$ years & 69 & 63.3 \\
\hline \multirow{2}{*}{$\begin{array}{l}\text { Place where the resident } \\
\text { lives during the training }\end{array}$} & Parent/ relative house & 52 & 46.8 \\
\hline & $\begin{array}{l}\text { Dormitory/ own or rental } \\
\text { apartment }\end{array}$ & 59 & 53.2 \\
\hline \multirow{2}{*}{$\begin{array}{l}\text { Current Medical Treat- } \\
\text { ment }\end{array}$} & No treatment & 91 & 82.0 \\
\hline & $\begin{array}{l}\text { Under psychiatric medi- } \\
\text { cation }\end{array}$ & 4 & 3.6 \\
\hline \multirow{3}{*}{$\begin{array}{l}\text { Mental health treatment } \\
\text { (present or previous) }\end{array}$} & Never & 88 & 79.3 \\
\hline & Psychotherapy & 14 & 12.6 \\
\hline & $\begin{array}{l}\text { Medication and psycho- } \\
\text { therapy }\end{array}$ & 9 & 8.1 \\
\hline \multirow{2}{*}{$\begin{array}{l}\text { Family Psychiatric } \\
\text { History }\end{array}$} & Presence in any relative & 34 & 30.6 \\
\hline & $\begin{array}{l}\text { Presence in father or } \\
\text { mother }\end{array}$ & 17 & 15.3 \\
\hline
\end{tabular}

$P=0.005)$, which showed lower BDI score for those with larger social network. At T2, it was found a statistically significant difference between interns at clinical and surgical programs (BDI mean score of $6.25 \pm 5.63$ vs. $8.19 \pm 5.57 ; \mathrm{z}=-2.23, \mathrm{P}=0.026$ ); it was found a higher BDI score in surgery than in other group (Table 2).

The mean of the BDI score variation was 4.25 (standard deviation of 4.93). It was observed a range of symptoms from -8 (decreasing symptomatology) to 28 (increasing symptomatology). The median of the BDI-variation was 3.00 .

Table 3 shows three linear regression models to evaluate the BDI score variation in eight months: univariate, multivariate with all independent variables and the final multivariate model. Considering the controlling variables - gender, age and specialty - only specialty area showed an association between BDI score variation and the surgical intern. This means that surgical interns had 2 more points of BDI score after 8 months than clinical interns. In multivariate regression models, as gender and age, specialty had no statistically significance, due to other variables in the models. Other factor, dissatisfaction with own performance, also presented a significant value when analysed by univariate model; $(\mathrm{P}<0.001)$,

TABLE 2. BDI MEAN DISTRIBUTION AT T1 AND T2 RELATED TO SOCIO-DEMOGRAPHIC CHARACTERISTICS

\begin{tabular}{|c|c|c|c|c|c|}
\hline & & \multicolumn{2}{|l|}{ T1 } & \multicolumn{2}{|l|}{$\mathrm{T} 2$} \\
\hline & & Mean \pm SD & $\mathrm{P}$ & Mean \pm SD & $\mathrm{P}$ \\
\hline \multirow[t]{2}{*}{ Gender } & Male & $2.85 \pm 3.38$ & \multirow[t]{2}{*}{.663} & $6.91 \pm 5.79$ & \multirow[t]{2}{*}{.841} \\
\hline & Female & $2.64 \pm 3.22$ & & $7.09 \pm 5.88$ & \\
\hline \multirow{2}{*}{$\begin{array}{l}\text { Residency Pro- } \\
\text { grams }\end{array}$} & Clinical & $2.78 \pm 3.35$ & \multirow[t]{2}{*}{.887} & $6.25 \pm 5.63$ & \multirow[t]{2}{*}{.026} \\
\hline & Surgical & $2.70 \pm 3.23$ & & $8.19 \pm 5.57$ & \\
\hline \multirow[t]{2}{*}{ Medical School } & $\begin{array}{l}\text { The same } \\
\text { that the sub- } \\
\text { ject is intern }\end{array}$ & $2.59 \pm 3.09$ & \multirow[t]{2}{*}{.382} & $7.29 \pm 5.99$ & \multirow[t]{2}{*}{.618} \\
\hline & Other & $3.09 \pm 3.58$ & & $6.53 \pm 5.14$ & \\
\hline \multirow{2}{*}{$\begin{array}{l}\text { Years living in } \\
\text { São Paulo }\end{array}$} & $\geq 6$ years & $2.39 \pm 3.05$ & \multirow[t]{2}{*}{.063} & $6.99 \pm 5.12$ & \multirow[t]{2}{*}{.568} \\
\hline & $<6$ years & $3.48 \pm 3.64$ & & $7.10 \pm 6.10$ & \\
\hline \multirow{2}{*}{$\begin{array}{l}\text { Place where } \\
\text { the resident } \\
\text { lives during the } \\
\text { training }\end{array}$} & $\begin{array}{l}\text { Parent/Rela- } \\
\text { tive house }\end{array}$ & $1.96 \pm 2.92$ & \multirow[t]{2}{*}{.005} & $7.48 \pm 5.26$ & \multirow[t]{2}{*}{.466} \\
\hline & $\begin{array}{l}\text { Dormitory/ } \\
\text { own or rental } \\
\text { apart }\end{array}$ & $3.44 \pm 3.46$ & & $6.58 \pm 5.78$ & \\
\hline \multirow[t]{2}{*}{ Marital status } & $\begin{array}{l}\text { Single/Di- } \\
\text { vorced }\end{array}$ & $2.65 \pm 3.24$ & \multirow[t]{2}{*}{.135} & $6.91 \pm 1.00$ & \multirow[t]{2}{*}{.129} \\
\hline & Married & $4.80 \pm 4.15$ & & $9.00 \pm 1.00$ & \\
\hline
\end{tabular}

NS = non-significant, $\mathrm{SD}=$ standard deviation 
TABLE 3. SIMPLE AND MULTIVARIATE LINEAR REGRESSION STUDIES OF BDI SCORE VARIATION IN EIGHT MONTHS OF MEDICAL RESIDENCY ACCORDING TO DISSATISFACTION, DIFFICULTIES AND STRESSFUL RELATIONSHIPS WITH THE TRAINING

\begin{tabular}{|c|c|c|c|c|c|c|}
\hline & \multirow{3}{*}{$\begin{array}{l}\text { Univariate Model } \\
\text { Coefficient (C195\%) }\end{array}$} & \multicolumn{5}{|c|}{ Multivariate Model } \\
\hline & & \multicolumn{2}{|c|}{$\begin{array}{l}\text { Initial Model } \\
\text { (Method "Enter") }\end{array}$} & \multicolumn{2}{|c|}{$\begin{array}{l}\text { Final Model } \\
\text { (Method "Backward") }\end{array}$} & \multirow[b]{2}{*}{$\mathrm{P}$} \\
\hline & & $\mathrm{P}$ & Coefficient (C195\%) & $\mathrm{P}$ & Coefficient (C195\%) & \\
\hline Gender male (ref. = female) & $-0.39(-2.26 ; 1.47)$ & 0.678 & $-0.90(-2.62 ; 0.81)$ & 0.299 & - & NS \\
\hline Medical Specialty surgical (ref. = clinical) & $2.02(0.14 ; 3.89)$ & 0.035 & $1.48(-0.42 ; 3.39)$ & 0.126 & - & NS \\
\hline Age (years) & $0.09(-0.64 ; 0.82)$ & 0.803 & $0.07(-0.55 ; 0.70)$ & 0.812 & - & NS \\
\hline $\begin{array}{l}\text { How unsatisfied are you with the professional } \\
\text { training you are acquiring? }\end{array}$ & $3.88(1.46 ; 6.30)$ & 0.002 & $3.21(0.2 ; 6.22)$ & 0.037 & $3.44(1.16 ; 5.72)$ & 0.004 \\
\hline $\begin{array}{l}\text { How unsatisfied are you with the amount of } \\
\text { leisure time you have? }\end{array}$ & $3.37(1.47 ; 5.27)$ & 0.001 & $1.99(-0.13 ; 4.1)$ & 0.065 & - & NS \\
\hline $\begin{array}{l}\text { How unsatisfied are you with your personal life } \\
\text { (time spent with family, romantic relationship } \\
\text { and friends)? }\end{array}$ & $3.55(1.75 ; 5.35)$ & $<0.001$ & $1.87(-0.11 ; 3.85)$ & 0.064 & $2.97(1.24 ; 4.70)$ & 0.001 \\
\hline $\begin{array}{l}\text { How unsatisfied are you with your personal } \\
\text { health habits (time for sports, healthy }\end{array}$ & $2.34(-0.1 ; 4.77)$ & 0.060 & $-0.56(-2.97 ; 1.86)$ & 0.648 & - & NS \\
\hline $\begin{array}{l}\text { How unsatisfied are you with the school } \\
\text { faculty? }\end{array}$ & $0.27(-1.75 ; 2.29)$ & 0.790 & $-2.97(-5.25 ;-0.70)$ & 0.011 & - & NS \\
\hline $\begin{array}{l}\text { How unsatisfied are you with the nursing team } \\
\text { that works with you? }\end{array}$ & $1.89(-0.03 ; 3.80)$ & 0.053 & $1.62(-0.23 ; 3.46)$ & 0.085 & $1.95(0.25 ; 3.65)$ & 0.025 \\
\hline $\begin{array}{l}\text { How unsatisfied are you with residency col- } \\
\text { leagues from all programs that you work with? }\end{array}$ & $-1.15(-5.26 ; 2.97)$ & 0.582 & $-1.88(-6.27 ; 2.51)$ & 0.396 & - & NS \\
\hline $\begin{array}{l}\text { During these } 8 \text { months of residency, how un- } \\
\text { satisfied are you with your own performance? }\end{array}$ & $5.99(2.94 ; 9.04)$ & $<0.001$ & $0.88(-2.9 ; 4.65)$ & 0.645 & - & NS \\
\hline How difficult for you is to deal with patients? & $-0.58(-3.36 ; 2.20)$ & 0.680 & $-2.37(-5.41 ; 0.66)$ & 0.124 & - & NS \\
\hline $\begin{array}{l}\text { How difficult for you is to deal with patient' } \\
\text { family? }\end{array}$ & $-0.33(-2.80 ; 2.14)$ & 0.792 & $0.86(-2.48 ; 4.20)$ & 0.609 & - & NS \\
\hline $\begin{array}{l}\text { How stressful is giving bad news for patients } \\
\text { and their families? }\end{array}$ & $1.13(-0.72 ; 2.98)$ & 0.230 & $1.04(-0.76 ; 2.84)$ & 0.253 & - & NS \\
\hline $\begin{array}{l}\text { How well oriented are you by the school } \\
\text { faculty? }\end{array}$ & $0.62(-1.57 ; 2.82)$ & 0.574 & $0.00(-2.25 ; 2.25)$ & 0.999 & - & NS \\
\hline $\begin{array}{l}\text { How well respected are you by the school } \\
\text { faculty? }\end{array}$ & $-0.73(-2.93 ; 1.47)$ & 0.511 & $-1.10(-3.33 ; 1.13)$ & 0.330 & - & NS \\
\hline $\begin{array}{l}\text { How stressful is the relationship with the nurse } \\
\text { team and other health professionals in the } \\
\text { hospital? }\end{array}$ & $1.75(-0.54 ; 4.04)$ & 0.132 & $1.21(-1.01 ; 3.42)$ & 0.281 & - & NS \\
\hline $\begin{array}{l}\text { How stressful is the relationship with 1st year } \\
\text { residents? }\end{array}$ & $0.18(-2.97 ; 3.32)$ & 0.910 & $1.11(-2.20 ; 4.42)$ & 0.507 & - & NS \\
\hline $\begin{array}{l}\text { How stressful is the relationship with } 2^{\text {nd }}, 3^{\text {rd }} \\
\text { and } 4^{\text {th }} \text { year residents? }\end{array}$ & $3.24(0.71 ; 5.76)$ & 0.013 & $3.43(0.78 ; 6.08)$ & 0.012 & $2.91(0.58 ; 5.25)$ & 0.015 \\
\hline $\begin{array}{l}\text { How stressful is the relationship with under- } \\
\text { graduate medical students? }\end{array}$ & $1.04(-3.96 ; 6.03)$ & 0.682 & $-1.95(-6.32 ; 2.42)$ & 0.376 & - & NS \\
\hline $\begin{array}{l}\text { How many hours per week are you working at } \\
\text { this rotation (including nightshifts)? }\end{array}$ & $0.05(0.00 ; 0.10)$ & 0.041 & $-0.01(-0.06 ; 0.04)$ & 0.732 & - & NS \\
\hline $\begin{array}{l}\text { How many hours per week are you working } \\
\text { outside the university this month (including } \\
\text { nightshifts)? }\end{array}$ & $0.10(-0.02 ; 0.22)$ & 0.118 & $0.04(-0.07 ; 0.15)$ & 0.475 & - & NS \\
\hline
\end{tabular}

Cl 95\% - Confidence Interval 95\%; NS - non significant (the variable was not included in the model)

but no longer maintained this effect in multivariate models.

Final multivariate model showed that only four occupational characteristics were related to BDI score variation: dissatisfaction with professional training acquired ( $\mathrm{p}=0.004)$; dissatisfaction with per- sonal life ( $\mathrm{p}=0.001)$; dissatisfaction with the nursing team they work with $(\mathrm{p}=0.025)$; and feeling stressed in the relationship with $2^{\text {nd }}, 3^{\text {rd }}$ and $4^{\text {th }}$ year residents $(p=0.015)$. In this way, it was noted that residents who were not satisfied with professional training acquired, or with their personal life, or who said they 


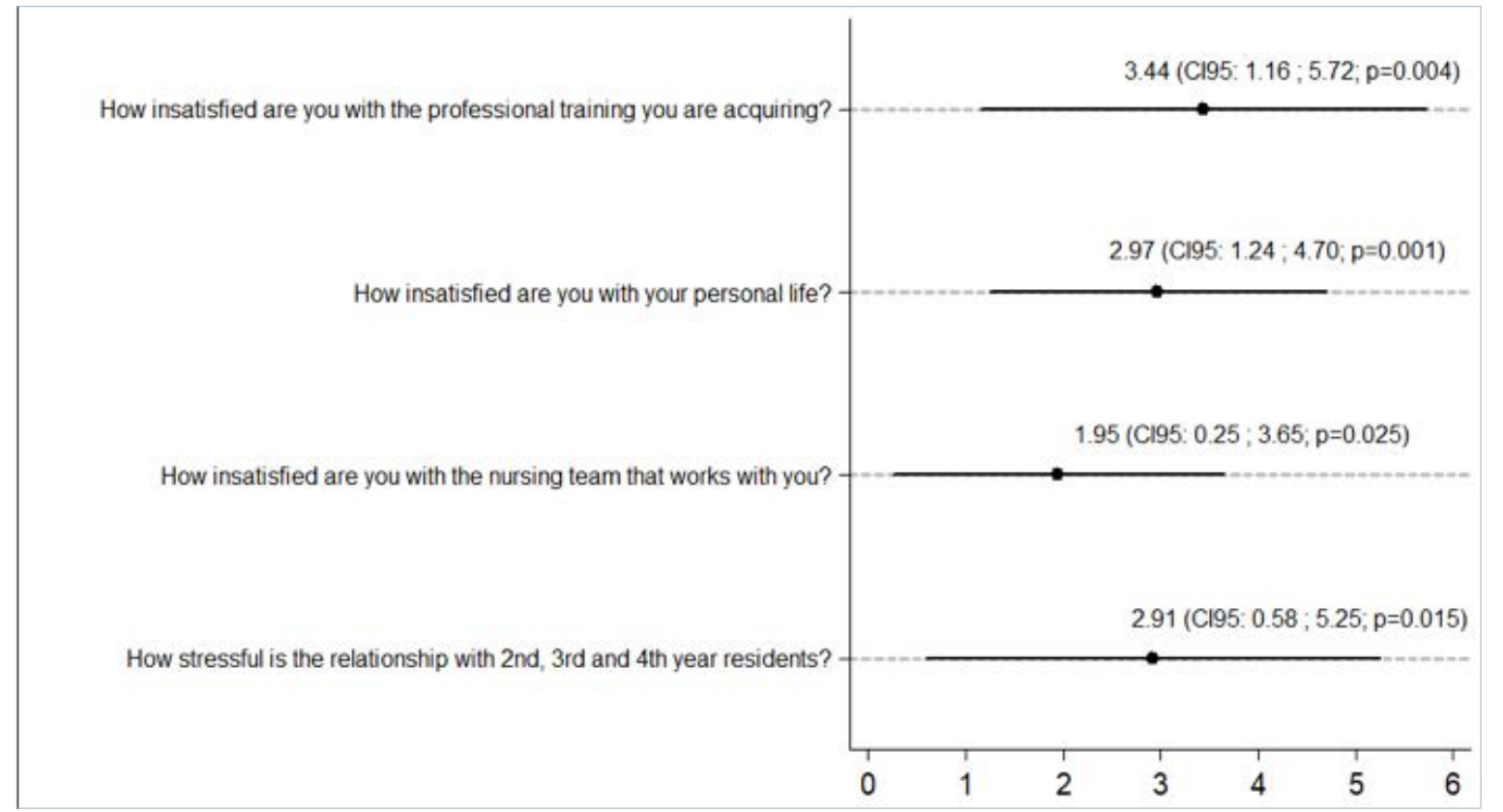

FIGURE 1 - COEFFICIENTS AND 95\% CONFIDENCE INTERVALS OF FINAL MULTIVARIATE REGRESSION MODEL OF BDI SCORE AFTER 8 MONTHS OF MEDICAL RESIDENCY

were feeling stressed in the relationship with $2^{\text {nd }}$, $3^{\text {rd }}$ and $4^{\text {th }}$ year residents presented 3 more points of BDI score after 8 months comparing to those without these perceptions. Being unsatisfied with the nursing team increased BDI score after 8 months in 2 more points. Figure 1 shows the impact of each one of these characteristics over the BDI score variation.

\section{DISCUSSION}

Increase in BDI score after 8 months of training and consequently the incidence of depressive symptoms of $9 \%$ (score $>15$ for depressive symptoms) reaffirm findings of increase in depressive symptoms during first year of medical residen$\mathrm{cy}^{3-6,},{ }^{3,11}$ It was found that the increase of depressive symptoms was related to some occupational characteristics such as dissatisfaction with personal life, dissatisfaction with the nursing team they work with, and feeling stressed in the relationship with seniors residents. Depressive symptoms were also related to dissatisfaction with professional training acquired.

Reflecting about the dissatisfaction with the nursing team, it has been described that enhancing nurse-intern partnerships are associated with improved provider satisfaction, patient satisfaction and the provision of individualized care. ${ }^{16}$ One as- sumption is that having an unsatisfactory relationship with the nursing team could affect directly or indirectly the resident-patient relationship. It would be relevant to investigate this assumption in further studies.

Although few studies were found discussing the relationship among medical residents from different years, some comments were identified in the literature revealing some reasons for interns to feel stressed in these relationships. ${ }^{12,} 17$ Lack of compassion, competitiveness and even cruelty abounds among them, problems not openly discussed but frequent in their clinical experience. ${ }^{17}$ One study specifically about surgery residents indicated that those individuals are more likely to prefer competition to cooperation..$^{18}$ In a study that examined job stress, satisfaction, and the psychological and social functioning of orthopaedic residents, it was found that residents had more psychiatric morbidity when the stress in relationships with senior residents is higher, whereas satisfaction from speaking with a mentor was associated with decreased morbidity. ${ }^{19}$ Competition is a reality of medical training and motivates the resident to do a better job; when excessive, however, it may lead to social isolation. ${ }^{12}$ Another aspect is an association between both lack of social skills and personal variables and depression in medical residents. ${ }^{10}$ 
There is a recommendation for the need for a strong working relationship, suggesting leaders of educational programs to address the relationship between interns - considering their conflicts, defining clear delineation of roles and a fair distribution of work, avoiding competition for clinical experiences. $^{20}$ Also relevant is a recommendation to provide teamwork and leadership training to clinicians in a way to affect stress levels. ${ }^{21}$ A protective factor against resident stress is camaraderie with peers. ${ }^{19}$

The association between depressive symptoms and dissatisfaction with professional training and personal life reaffirms findings from prior works described in the literature, ${ }^{1,6,8,9}$ in which some aspects of the training were observed such as long hours, sleep deprivation, limited time for personal pursuits, mood disturbances, among other factors. Still, it should not be neglected that these results related to these two variables - dissatisfaction with professional training and personal life - may reflect inherent characteristics of physicians such as being demanding and perfectionist professionals, ${ }^{4}$ and self-criticism, a significant predictor of depression for interns. ${ }^{8,22}$

Considering occupational characteristics, medical specialty was a factor related to depressive symptoms at T2. This characteristic was relevant when it was studied without considering other occupational characteristics; however, when different aspects of the training were analysed, medical specialty lacked significance. One possible explanation is that the impact of being a surgical or clinical specialty on depressive symptoms is assembled in one of the four variables that resulted as statistically relevant in the multivariate model. As a possibility, it may be that the variable "Satisfaction with nursing team" is already covering the specialty impact as the impact of the nursing team might be expected to be greater for surgical specialties.

About gender, it is an important influence to depression, being the prevalence in women usually twice higher than that of men. ${ }^{23}$ Studies about this issue for medical residents are unclear, suggesting that gender is not important. ${ }^{4,8,9,11}$ This is in concordance with our findings since there was no significant difference on gender in this study.

One aspect in the socio-demographic characteristics is that residents who lived in a parent' or relative' house presented a lower BDI score (T1) when compared with those who lived in dormitory or their own or rented house $(\mathrm{P}=0.005)$; this pattern could be attributed to receiving a good social support in the beginning of the medical training. After 8 months this aspect is no longer significant, which may be due to an adaptation process.

The findings from this study are limited to this group of entrants for residency at this university. For this particular sample, there are also some possible bias. Residents who chose not to participate may have done so because they wanted to avoid revealing themselves in testing, what might have changed the results. The rate of depressive symptoms might also be inaccurate doe to residents who answered what they thought it would to be more appropriated, instead of their actual feeling.

The relationship between depressive symptoms and dissatisfaction with the program is really a twoway causal relationship; always taking into account that depression is influenced by other characteristics such as personality traits, previous experiences, genetic aspects, etc.

This study raises some questions. Being the professional training unsatisfactory, is there something that could be done by interns to improve their experience? In addition, how do they cope with a stressful situation, and how do they use their spare time? Which actions can the intern develop by themselves? Could the program develop wellbeing strategies or tutorial programs for this population? Studying stressful and satisfactory aspects for residents may improve the discussion on critical actions for developing a better mental health during training. This study may motivate a new research about resilient residents, the impact of competitive behaviour on the quality of medical training.

\section{CONCLUSION}

The increase in BDI score after 8 months of training and consequently the incidence of depressive symptoms were related to some occupational characteristics as dissatisfaction with personal life, dissatisfaction with the nursing team they work with, feeling stressed in the relationship with senior residents, and dissatisfaction with professional training obtained. It is important to help these interns to improve their training experience and take care of their needs.

Among the many factors that interfere with depression incidence in interns (including personal as- 
pects), the occupational characteristics might be the only one that can be enhanced by the university that offers the training. Thus, addressing these dissatisfaction and stressful issues should provide the university better care of interns' mental health.

\section{ACKNOWLEDGMENT}

We thank the residents for their time in our efforts to collect the data.

Sources of funding: none.

Conflict of interests:none.

\section{RESUMO}

OBJETIVO: Estudar a incidência de sintomas depressivos em residentes de medicina de 10 ano e sua correlação com características ocupacionais, satisfação e estresse no programa.

MÉTODOs: Coorte prospectivo realizado na Escola Paulista de Medicina, Universidade Federal de São Paulo. Foram convidados 166 médicos residentes do hospital universitário para responder ao Inventário de Depressão Beck (BDI) e a um questionário ocupacional num estudo prospectivo longitudinal. O escore da variação do BDI foi relacionado com aspectos sociodemográficos e características ocupacionais usando um modelo de regressão linear.

RESULTADOS: Cento e onze sujeitos participaram (67\%); o escore do BDI aumentou em oito meses (média = 2,75 $\pm 3,29$ vs. 7,00 $\pm 5,66$; $p<0,0001$ ). A incidência dos sintomas depressivos foi de 9,01\% (escore $>75$ ).

A variação do escore do $B D I$ teve média $=4,25 \pm 4,93$ (de -8 a 28). Residentes não satisfeitos com o treinamento profissional $(\beta=3,44$; $p=0,004)$, com a vida pessoal $(\beta=2,97 ; p=0,001)$ ou que se sentem estressados na relação com residentes seniores $(\beta=2,91 ; p=$ $0,015)$ apresentaram 3 pontos a mais do escore do BDI depois de oito meses em comparação com aqueles sem tais percepções; estar insatisfeito com a equipe de enfermagem aumentou o escore do BDI em 2 pontos $(\beta=1,95 ; p=0,025)$.

CONCLUSÃo: Entre os fatores que interferem na depressão em residentes estão as características ocupacionais que podem ser melhoradas no treinamento. Esclarecer tais pontos pode ajudar a instituição a prover um melhor cuidado em saúde mental.

PALAVRAS-CHAVE: Depressão. Internato e residência. Estresse psicológico. Saúde mental. Educação médica.

\section{REFERENCES}

1. Resident Services Committee, Association of Program Directors in Internal Medicine. Stress and impairment during residency training: strategies for reduction, identification, and management. Ann Intern Med. 1988;109(2):154-61.

2. Reuben DB. Depressive symptoms in medical house officers. Effects of level of training and work rotation. Arch Intern Med. 1985;145(2):286-8.

3. Girard DE, Hickam DH, Gordon GH, Robison RO. A prospective study of internal medicine residents' emotions and attitudes throughout their training. Acad Med. 1991;66(2):111-4

4. Peterlini M, Tibério IF, Saadeh A, Pereira IC, Martins MA. Anxiety and depression in the first year of medical residency training. Med Educ. 2002;36(1):66-72.

5. Bellini LM, Shea JA. Mood change and empathy decline persist during three years of internal medicine training. Acad Med. 2005;80(2):164-7.

6. Rosen IM, Gimotty PA, Shea JA, Bellini LM. Evolution of sleep quantity, sleep deprivation, mood disturbances, empathy, and burnout among interns. Acad Med. 2006;81(1):82-5.

7. Fahrenkopf AM, Sectish TC, Barger LK, Sharek PJ, Lewin D, Chiang VW, et al. Rates of medication errors among depressed and burnt out residents: prospective cohort study. BMJ. 2008;336(7642):488-91.

8. Firth-Cozens J. Depression in doctors. In: Robertson MM, Katona CLE, eds. Depression and physical illness. Chichester: Wiley; 1997. p.95-114.

9. Sen S, Kranzler HR, Krystal JH, Speller H, Chan G, Gelernter J, et al. A prospective cohort study investigating factors associated with depression during medical internship. Arch Gen Psychiatry. 2010;67(6):557-65.

10. Pereira-Lima K, Loureiro SR, Crippa JA. Mental health in medical residents: relationship with personal, work-related, and sociodemographic variables. Rev Bras Psiquiatr. 2016;38(4):318-24

11. Mata DA, Ramos MA, Bansal N, Khan R, Guille C, Di Angelantonio E, et al. Prevalence of depression and depressive symptoms among resident physicians: a systematic review and meta-analysis. JAMA. 2015;314(22):2373-83.
12. Small GW. House officer stress syndrome. Psychosomatics. 1981;22(10):860-9.

13. Beck AT, Rush AJ, Shaw BF, Emery G. Terapia cognitiva da depressão. Porto Alegre: Artes Médicas; 1997.

14. Gorenstein C, Andrade L. Validation of a Portuguese version of the Beck Depression Inventory and the State-Trait Anxiety Inventory in Brazilian subjects. Braz | Med Biol Res. 1996;29(4):453-7.

15. Beck AT, Ward CH, Mendelson M, Mock J, Erbaugh J. An inventory for measuring depression. Arch Gen Psychiatry. 1961;4:561-71.

16. Benike LA, Clark JE. Enhancing nurse-resident physician partnerships. Creat Nurs. 2015;21(3):150-5.

17. Allen RK. These are a few of my favourite things: reflections on the doctor-doctor relationship. Intern Med J. 2005;35(1):65-6.

18. McGreevy J, Wiebe D. A preliminary measurement of the surgical personality. Am J Surg. 2002;184(2):121-5.

19. Sargent MC, Sotile W, Sotile MO, Rubash H, Barrack RL. Stress and coping among orthopaedic surgery residents and faculty. J Bone Joint Surg Am. 2004;86-A(7):1579-86.

20. Smith LG; Association of Professors of Medicine. Residency and subspecialty program directors: the need for a strong working relationship. Am J Med. 2003;115(3):256-8.

21. Firth-Cozens J. Doctors, their wellbeing, and their stress. BMJ. 2003;326(7391):670-1.

22. Brewin CR, Firth-Cozens J. Dependency and self-criticism as predictors of depression in young doctors. J Occup Health Psychol. 1997;2(3):242-6.

23. Almeida-Filho N, Mari JJ, Coutinho E, Franca JF, Fernandes JG, Andreoli $\mathrm{SB}$, et al. Estudo multicêntrico de morbidade psiquiátrica em áreas urbanas brasileiras (Brasília, São Paulo, Porto Alegre). Rev ABP-APAL. 1992;14(3):93-104. 